\title{
A Gompertz regression model for fern spores germination
}

\author{
Jose María Gabriel y Galán ${ }^{1 *}$, Carmen Prada ${ }^{1}$, Cristina Martínez-Calvo ${ }^{2}$, Rafael Lahoz-Beltráa \\ ${ }^{1}$ Department of Plant Sciences (Botany), Faculty of Biological Sciences, Universidad Complutense \\ de Madrid. Avda. José Antonio Nováis, 2; 28040, Madrid, Spain \\ ${ }^{2}$ Department of Applied Mathematics (Biomathematics), Faculty of Biological Sciences, Universidad \\ Complutense de Madrid. Avda. José Antonio Nováis, 2; 28040, Madrid, Spain
}

\begin{abstract}
Gabriel y Galán, J.M., Prada, C., Martínez-Calvo, C. \& Lahoz-Beltrá R. 2015. A Gompertz regression model for fern spores germination. Anales Jard. Bot. Madrid 72(1): e015

Germination is one of the most important biological processes for both seed and spore plants, also for fungi. At present, mathematical models of germination have been developed in fungi, bryophytes and several plant species. However, ferns are the only group whose germination has never been modelled. In this work we develop a regression model of the germination of fern spores. We have found that for Blechnum serrulatum, Blechnum yungense, Cheilanthes pilosa, Niphidium macbridei and Polypodium feuillei species the Gompertz growth model describe satisfactorily cumulative germination. An important result is that regression parameters are independent of fern species and the model is not affected by intraspecific variation. Our results show that the Gompertz curve represents a general germination model for all the non-green spore leptosporangiate ferns, including in the paper a discussion about the physiological and ecological meaning of the model.
\end{abstract}

Keywords: Leptosporangiate ferns, mathematical model, non-green spore, spore germination modelling

\section{INTRODUCTION}

Germination is one of the most important biological processes for plants, relevant from a strictly individual aspect as well as for the population recruitment. It is defined, for both seed and spore plants, also for fungi as the set of mechanisms occurring in the dormant germ (seed or spore) that culminates with the growth of the embryo or cell to form a seedling or sporeling able to establish in the substrate. Generally, germination can be easily detected by observing signs of a body emergence, as radicle, protonema, filament or rhizoid (Bradbeer, 1988). More complex techniques could be used to detect in situ vitality, biochemical reactions, enzymatic activity, metabolite usage, etc., all of them symptoms of pre-germination processes. Germination has been widely studied from physiological and ecological perspectives (cf extensive synthesis on the topic in, among others, Thompson, 1973; Bewley, 1997; Baskin \& Baskin, 1998; Finch-Savage \& Leubner-Metzger, 2006). From a taxonomical view most works have focussed on seed plants, especially those with economical, agricultural or biomedical value. Germination dynamics of fungal and bacteria spores are also of interest, particularly those

\section{Resumen}

Gabriel y Galán, J.M., Prada, C., Martínez-Calvo, C. \& Lahoz-Beltrá R. 2015. Un modelo de regresión de Gompertz para germinación de esporas de helechos. Anales Jard. Bot. Madrid 72(1): e015

La germinación es uno de los procesos biológicos más relevantes tanto para las plantas con esporas, como para las plantas con semillas y los hongos. Hasta el momento, se han desarrollado modelos de germinación para hongos, briofitos y diversas especies de espermatófitos. Los helechos son el único grupo de plantas cuya germinación nunca ha sido modelizada. En este trabajo se desarrolla un modelo de regresión para explicar la germinación de las esporas de helechos. Observamos que para las especies Blechnum serrulatum, Blechnum yungense, Cheilanthes pilosa, Niphidium macbridei y Polypodium feuillei el modelo de crecimiento de Gompertz describe satisfactoriamente la germinación acumulativa. Un importante resultado es que los parámetros de la regresión son independientes de la especie y que el modelo no está afectado por variación intraespecífica. Por lo tanto, los resultados del trabajo muestran que la curva de Gompertz puede representar un modelo general para todos los helechos leptosporangiados de esporas no verdes. Se incluyen, adicionalmente, comentarios sobre el significado fisiológico y ecológico del modelo.

Palabras clave: Helechos leptosporangiados, modelo matemático, esporas no verdes, modelización de germinación de esporas

of pathological significance (Waggoner \& Parlange, 1973; Lapp \& Skoropad, 1976; Bosch \& al., 1995).

The mathematical models of germination describe germination based on two different approaches. The traditional approach uses indices, formulae and rates (Maguire, 1962; Ranal \& Garcia de Santana, 2006). In this approach a common mistake was the confusion between germination speed and percentage of germination. Later on germination kinetics studies were mostly conducted based on a different approach consisting in fitting a S-shaped curve to cumulative germination across time (Hsu \& al., 1984). Following this view, most studies made special emphasis on goodness of fit and computational cost of curve fitting. Different types of curve can be used to describe cumulative germination, e.g. Gompertz, logistic, Weibull, Morgan-MercerFloding, Richards, asymptotic exponential, etc. (Brown \& Mayer, 1988) allowing germination to be summarized with a few curve parameters. However, only a few studies in germination or related fields in biological modeling techniques made emphasis on the biological interpretation of geometric parameters (Fitzhugh, 2011). Studying the dynamic of such parameters we can detect a summary of the underlying biological mechanism. In addition to curve analysis, 
polynomial regression has been used to fit the germination curve (Goodchild \& Walker, 1971).

An advantage of the study of the standard pattern of germination could be relevant in order to evaluate the effects of environmental variables on the species dynamics and its life cycle. For instance, with the help of a normal cumulative curve as a mathematical model of spore germination in fungi, Waggoner and Parlange (Waggoner \& Parlange, 1973 ) were able to choose the type fungicide and the time of spraying in potato and tomato treatments. Also, application of germination models in population dynamics is its utility to detect when a single dataset consists of several subpopulations revealing the plot of cumulative germination one or more steps (O'Neill \& al., 2004). At the present, germination models of fungi (Dantigny \& al., 2011), bryophytes (Wiklund \& Rydin, 2004) and several seed plant species, e.g. fennel seeds (Torres \& Frutos, 1990), meadowfoam plants (Cheng \& Gordon, 2000), grasses (Brown \& Mayer, 1988), have been published.

Ferns, with more than 9,000 species, are the second most successful lineage of vascular plants, after angiosperms. They have a long evolutionary history related to important events as the origin of land plants and emergence of the seed. Ferns are significant ecological elements in tropical ecosystems, where they can also be dominant. Some species have enormous importance for humans, as invasive plants (for example, Pteridium aquilinum (L.) Kuhn, Salvinia molesta D.S. Mitch. and Lygodium japonicum (Thunb.) Sw.) and as toxic species for cattle (Pteridium aquilinum), with strong economic impact (Prada, 2004). In recent years we have conducted several studies on germinating fern spores: developmental observations (Gabriel y Galán \& al., 2008a; Gabriel y Galán \& al., 2008b; Gabriel y Galán \& Prada, 2009; Gabriel y Galán \& Prada, 2010a; Gabriel y Galán \& Prada, 2010b; Migliaro \& Gabriel y Galán, 2012), physiological studies (Gabriel y Galán \& Prada, 2010c), reproductive biology reviews (Prada \& al., 2008; Gabriel y Galán, 2010; Gabriel y Galán, 2011), ecological analyses (Gabriel y Galan \& al., 2011) and taxonomical/phylogenetical studies (Gabriel y Galán \& Prada, 2012) of both the spore and/or the fern gametophyte that arise when the spore germinates. Even when physiological and ecological aspects of fern spore germination have been extensively studied (Weinberg \& Voeller, 1969; Lloyd \& Klekowski, 1970; Raghavan, 1989; Sheffield, 1996; Gabriel y Galán \& Prada, 2010c) surprisingly this is the only group of plants where germination has never been statistically modelled. Some observations describe cumulative germination over time exhibiting a pattern as follows: begins slowly, accelerates rapidly, and then declines as maximum germination percentage is reached. In the case of ferns, the lack of germination models led us to establish whether germination of fern spores followed some defined regression model.

In this paper we study two different but related issues. First, since germination fits well to a sigmoid function, we studied if Gompertz model could represents a common pattern of germination for non-green spore leptosporangiate ferns. Secondly, since it is known that Gompertz function parameters have a clear biological interpretation, we studied whether the observed variation of these parameters depend on the fern species. The study of these parameters ould produce relevant ecophysiological observations.

\section{MATERIALS AND METHODS}

\section{Plant material, spores sowing and germination observation}

Five species were selected to study spore germination: Blechnum serrulatum Rich. and Blechnum yungense Ramos Giacosa (Blechnaceae), Cheilanthespilosa Goldm. (Pteridaceae), Niphidium macbridei Lellinger and Polypodium feuillei Bertero (Polypodiaceae). Two criteria influenced this selection: a) all of them are species whose spores lack chlorophyll, as the presence of this pigment in the spore is known to drastically reduce their viability in a few days or weeks (Gabriel y Galán \& Prada, 2010c); and b) to test the general value of the model for the ferns as a whole, we chose some species within the same genus (B. serrulatum and B. yungense), different genera from the same family (Niphidium and Polypodium) and from different families (Blechnaceae, Pteridaceae and Polypodiaceae).

All plants came from natural populations and not from cultivation. After collection, individuals were dried out and maintained at room temperature preserved from light sources. At the time of sowing, spores were of less than a month from field collection, in order to guarantee its presumable viability.

To test if the germination model is affected by variation between individuals some experiments were conducted using spores of the same individual and other mixing spores from different individuals. Spores thus obtained were sowed in agar nutritive medium (Dyer, 1979) in Petri dishes of $6 \mathrm{~cm}$ in diameter. Three replicates were sown in each case (two dishes in the case of $B$. yungense due to a low amount of spores). Petri dishes were introduced in cultivation chambers and grown under fluorescent light on a 12 -hour photoperiod cycle at an isothermic regime of $20 \pm 2{ }^{\circ} \mathrm{C}$.

Germination was recorded every day at approximately the same hour for the first 12 days, and then every 3 days until no further increase was detected. Under a compound light microscope, germinated spores were counted from a pool of 100 spores randomly selected in each Petri dish, excluding those abortive or irregularly formed. A spore was considered germinated when a first rhizoid was evident emerging from the opened spore wall.

The raw germination data, percentage germination $y(\%)$ versus time $t$ (days), were obtained for Blechnum serrulatum, Blechnum yungense, Cheilanthes pilosa, Niphidium macbridei and Polypodium feuillei.

\section{Model equation and data analysis}

The Gompertz regression analysis of data was conducted using the methods outlined in Appendix. A comparison was made between the modelling by the Gompertz nonlinear regression equation and the logistic equation. Model comparisons were conducted with B. serrulatum and P. feuillei germination data.

\section{RESULTS}

All of the curves visually gave reasonable good fitting of the data to Gompertz model. We have found that for B. serrulatum, B. yungense, C. pilosa, N. macbridei and P. feuillei species the 
Table 1. Gompertz germination equation for fern spores

\begin{tabular}{ll}
\hline B. serrulatum & $y=2 e^{19.0612\left(e^{-1.6926}-e^{-0.2418 t}\right)}$ \\
B. yungense & $y=e^{8.4065\left(e^{-0.6108}-e^{-0.3054 t}\right)}$ \\
C. pilosa & $y=2 e^{12.3393\left(e^{-1.17}-e^{-0.2340 t}\right)}$ \\
N. macbridei & $y=e^{5.6366\left(e^{-0.2191}-e^{-0.2191 t}\right)}$ \\
P. feuillei & $y=e^{5.4927\left(e^{-0.1940}-e^{-0.1940 t}\right)}$
\end{tabular}

Gompertz model describe cumulative germination, providing a consistently good fit for the data (Table 1).

Germination regression curves obtained for each of the fern species are shown in Figures 1-5. A summary of the error measurements indices, coefficient of determination $\mathrm{R}^{2}$ and Durbin-Watson statistic for each specie and replicate is shown in Table 2.

In B. yungense Durbin-Watson test is less than 1.0 , which would indicate some autocorrelation in germination data. However, in B. serrulatum there is a statistical evidence of absence of autocorrelation. For the rest of the species the presence or absence of autocorrelation varies from one experimental replicate to another. However, once influential points in germination were identified (Table 3 ) and removed (Table 4) in further analysis Durbin-Watson statistic, error measurements indices and coefficient of determination $\mathrm{R}^{2}$ were improved vanishing autocorrelation. It is important to
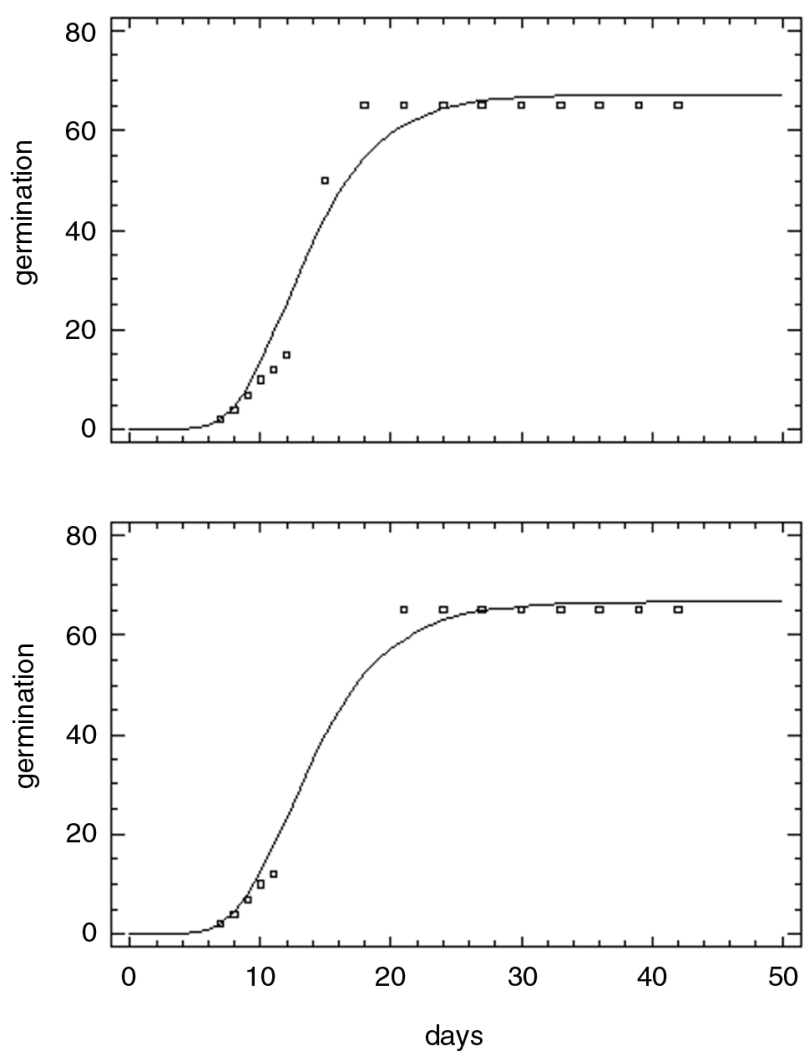

Fig. 1. Spores germination curve over days illustrating the nature of the Gompertz function for $B$. serrulatum (top) including influential points (bottom) without influential points and equation shown in Table 1.
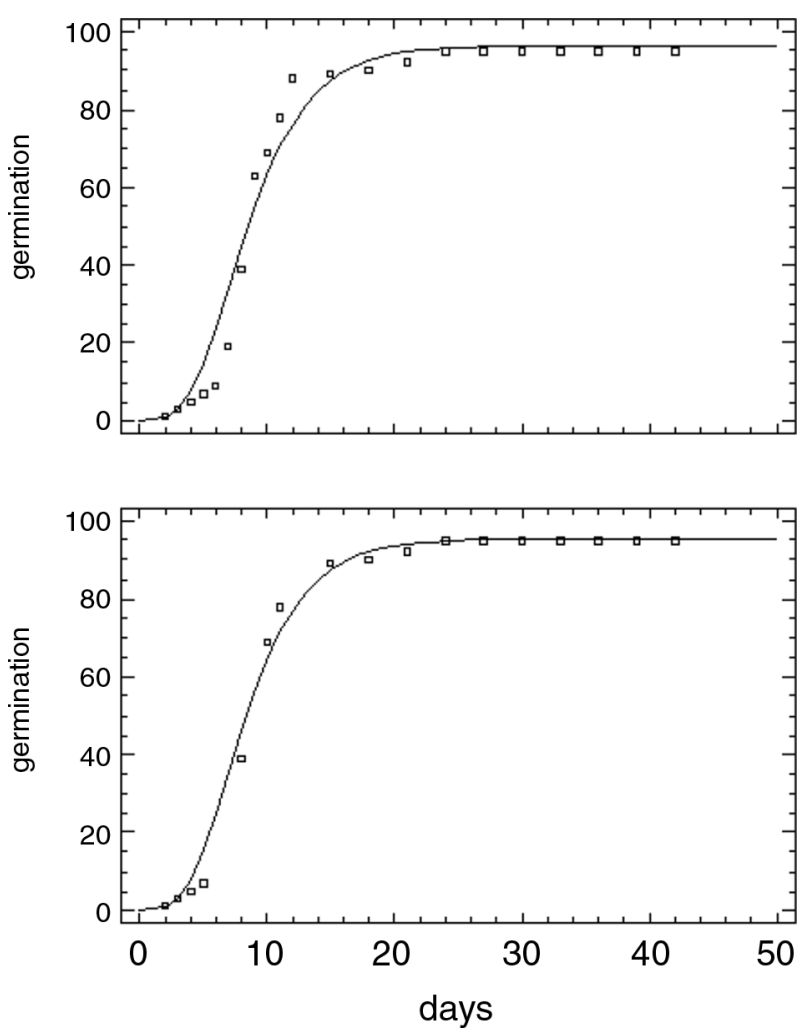

Fig. 2. Spores germination curve over days illustrating the nature of the Gompertz function for $B$. yungense (top) including influential points (bottom) without influential points and equation shown in Table 1.
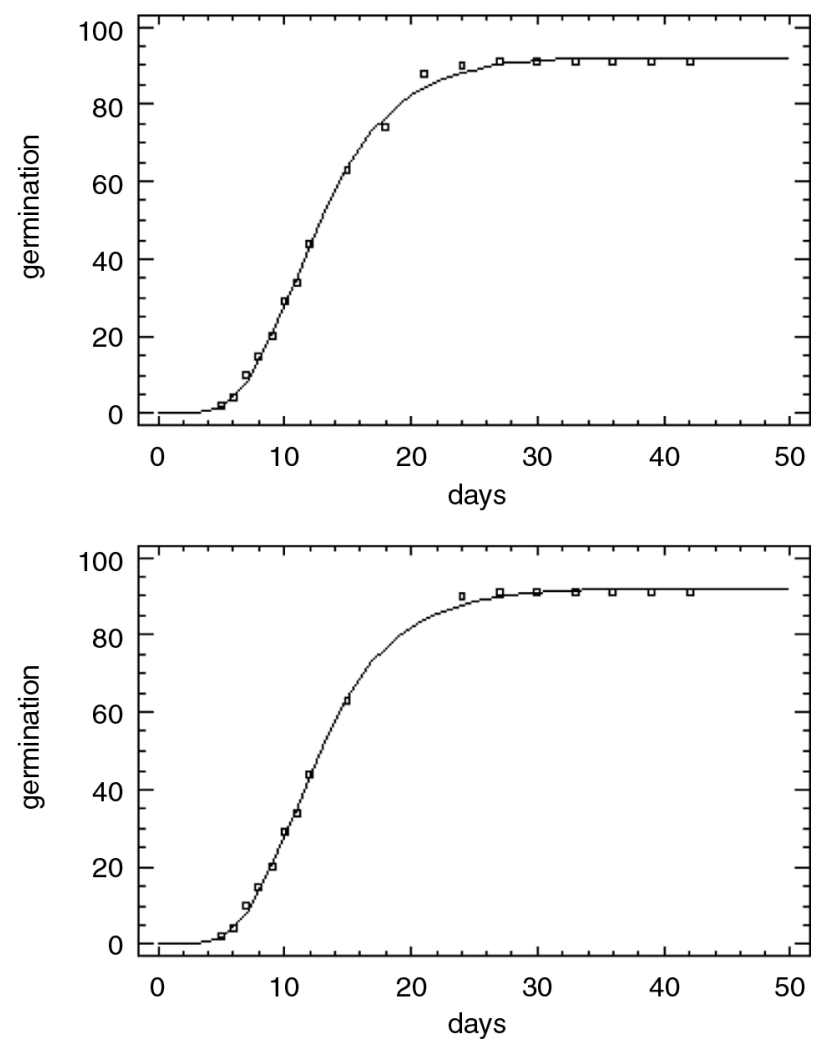

Fig. 3. Spores germination curve over days illustrating the nature of the Gompertz function for C. pilosa (top) including influential points (bottom) without influential points and equation shown in Table 1. 

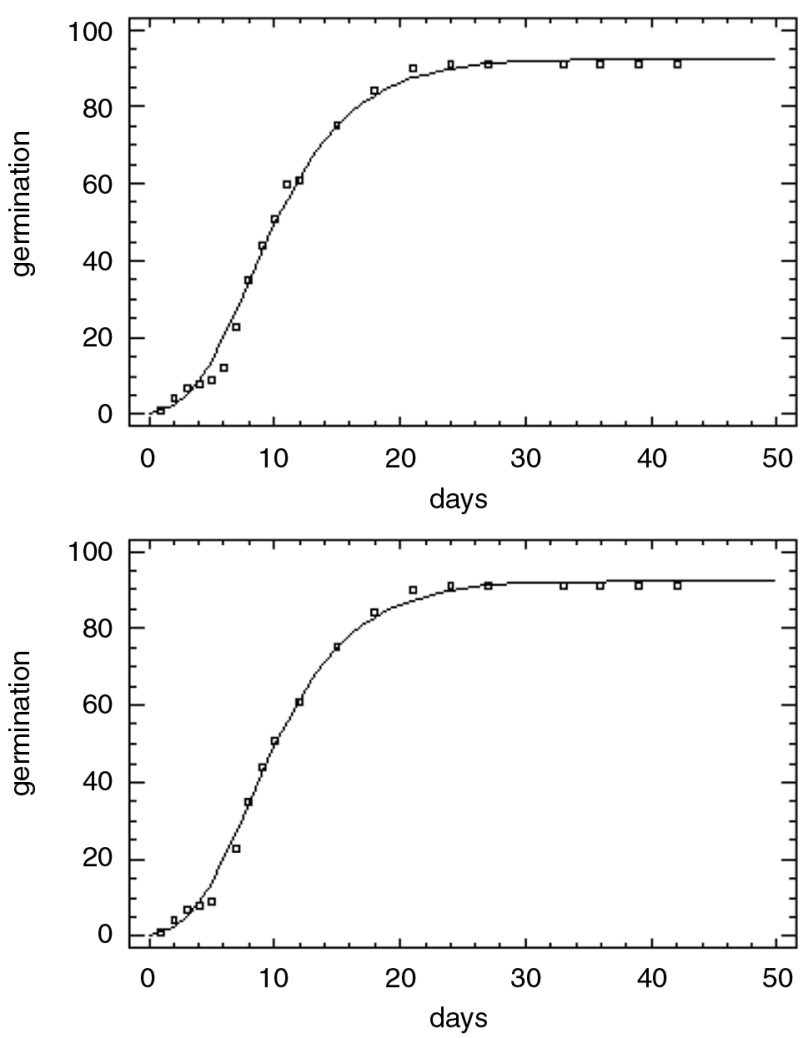

Fig. 4. Spores germination curve over days illustrating the nature of the Gompertz function for N. macbridei (top) including influential points (bottom) without influential points and equation shown in Table 1.
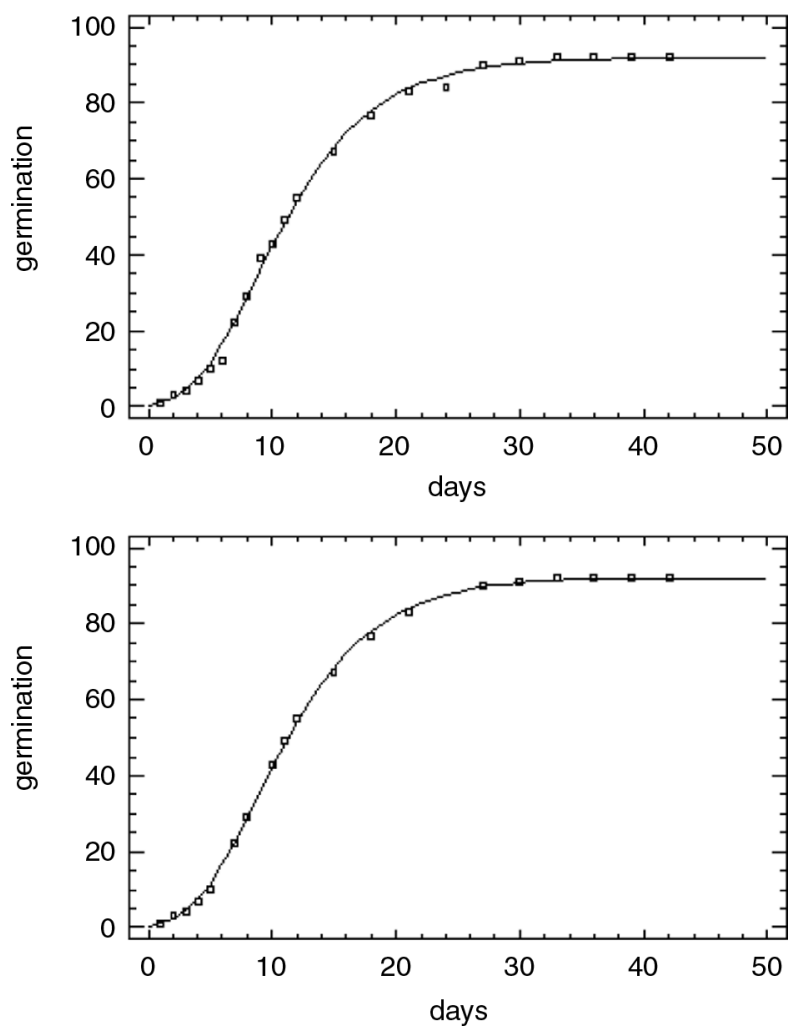

Fig. 5. Spores germination curve over days illustrating the nature of the Gompertz function for P. feuillei (top) including influential points (bottom) without influential points and equation shown in Table 1.
Table 2. Gompertz nonlinear regression statistics for fern spores germination

\begin{tabular}{|c|c|c|c|c|c|}
\hline & Replicate & MSE & MAE & $\mathbf{R}^{2}$ & $\begin{array}{c}\text { Durbin-Watson } \\
\text { statistic }\end{array}$ \\
\hline \multirow{3}{*}{ B. serrulatum } & 1 & 85.865 & 6.599 & 94.362 & 1.079 \\
\hline & 2 & 31.789 & 3.871 & 96.690 & 1.308 \\
\hline & $3 *$ & 26.247 & 3.468 & 96.869 & 1.102 \\
\hline \multirow{2}{*}{ B. yungense } & 1 & 48.112 & 4.677 & 96.901 & 0.502 \\
\hline & $2^{*}$ & 46.868 & 4.553 & 96.998 & 0.596 \\
\hline \multirow{3}{*}{ C. pilosa } & $1 *$ & 2.493 & 1.149 & 99.818 & 1.938 \\
\hline & 2 & 5.181 & 1.425 & 99.525 & 1.145 \\
\hline & 3 & 11.034 & 1.946 & 98.954 & 0.486 \\
\hline \multirow{3}{*}{ N. macbridei } & $1 *$ & 8.573 & 1.976 & 99.367 & 0.716 \\
\hline & 2 & 13.473 & 2.627 & 99.050 & 0.572 \\
\hline & 3 & 9.498 & 2.194 & 99.265 & 0.993 \\
\hline \multirow{3}{*}{ P. feuillei } & 1 & 14.862 & 2.587 & 98.005 & 0.748 \\
\hline & 2 & 7.925 & 2.042 & 99.254 & 0.669 \\
\hline & $3^{*}$ & 2.831 & 1.118 & 99.787 & 1.340 \\
\hline
\end{tabular}

${ }^{*}$ ) best model selected for further analysis.

Table 3. Gompertz influential points for fern spores germination

\begin{tabular}{lccc}
\hline & $\boldsymbol{y}$ (day) & \multicolumn{1}{c}{ DFITS } & Cook's distance \\
\hline B. serrulatum & 6 & -1.4350 & 0.1156 \\
OMl=0.125 & 7 & 1.2133 & 0.1352 \\
B. yungense & 8 & 1.3833 & 0.1042 \\
& 5 & -0.7111 & 0.0127 \\
OMl=0.0952 & 6 & -1.0236 & 0.0412 \\
C. pilosa & 8 & 0.6407 & 0.0277 \\
OMl=0.1111 & 11 & 0.7146 & 0.0229 \\
N. macbridei & 11 & -0.7858 & 0.0314 \\
OMl=0.0952 & 6 & -0.8861 & 0.0341 \\
P. feuillei & 11 & 0.7170 & 0.0112 \\
OMl=0.0909 & 6 & -0.6980 & 0.0303 \\
\hline
\end{tabular}

$\mathrm{OMI}=$ Observation mean influence.

note that germination equations for fern spores shown in Table 1 were obtained fitting data without the influential points shown in Table 3. Furthermore, in germination equations $\alpha$ parameter disappear whereas it is preserved during regression analysis when fitting is conducted including influential points.

In Figure 6 we show a Box-and-Whisker plot of parameter $r$ in the five fern species studied in this paper. The KruskalWallis test shows with a $p$-value equal to 0.0735 that there is not a statistically significant difference among the medians at the $95.0 \%$ confidence level. In consequence, we conclude that $r$, thus the instantaneous germination rate, does not depend on species. A similar result is obtained with $\alpha$. According to 
Table 4. Gompertz nonlinear regression statistics for fern spores germination without influential points

\begin{tabular}{lrrcc}
\hline & MSE & MAE & $\mathbf{R}^{2}$ & $\begin{array}{c}\text { Durbin-Watson } \\
\text { statistic }\end{array}$ \\
\hline B. serrulatum & 7.604 & 1.777 & 99.197 & 1.956 \\
B. yungense & 13.957 & 2.219 & 99.125 & 1.087 \\
C. pilosa & 1.233 & 0.848 & 99.915 & 1.936 \\
N. macbridei & 4.413 & 1.490 & 99.687 & 0.887 \\
P. feuillei & 0.644 & 0.611 & 99.954 & 1.248
\end{tabular}

Figure 7 and Kruskal-Wallis test ( $p$-value equal to 0.1090) we can conclude that also $\alpha$ (thus, the rate modeling the decreasing of $r$ ) does not depend on species. Furthermore, and based on these analyses, we concluded that germination model is not affected by using spores from the same individual or from different individuals. Note that Box-and-Whisker plot of parameters were obtained when regression analysis was conducted including influential points.

The logistic nonlinear regression statistic for Blechnum serrulatum and Polypodium feuillei spores germination is shown in Table 5. Model comparison results are shown in Tables 6-7. Figure 8 depicts the scatter plot and logistic nonlinear regression curve in both species. Although B. serrulatum fits to both germination models, as reported by the root mean

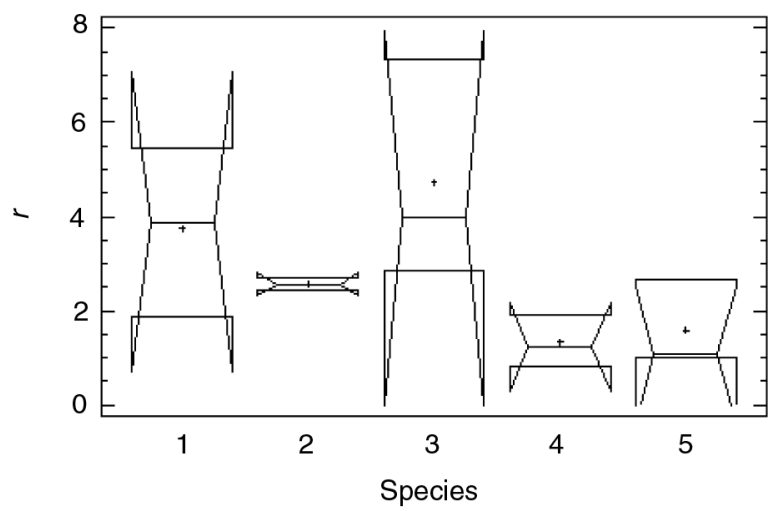

Fig. 6. Box-and-Whisker plot of parameter $r$ for (1) B. serrulatum, (2) B. yungense, (3) C. pilosa, (4) N. macbridei and (5) P. feuillei.

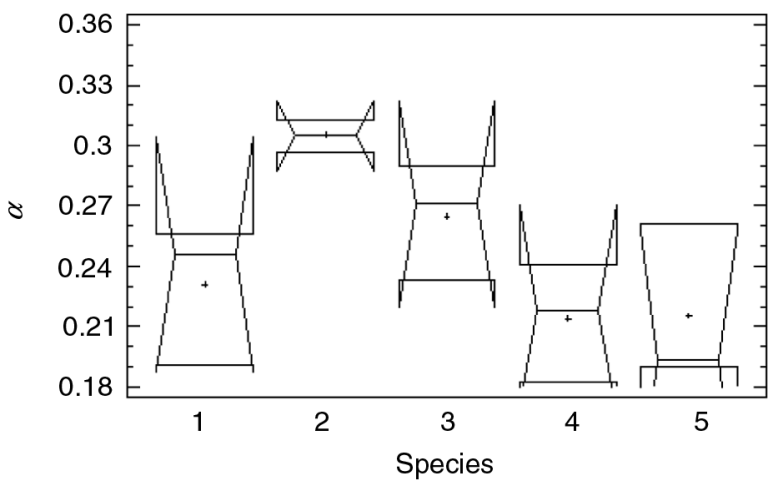

Fig. 7. Box-and-Whisker plot of parameter $\alpha$ for (1) B. serrulatum, (2) B. yungense, (3) C. pilosa, (4) N. macbridei and (5) P. feuillei.
Table 5. Logistic nonlinear regression statistics for fern spores germination

\begin{tabular}{lccccc}
\hline & Replicate & MSE & MAE & $\mathbf{R}^{2}$ & $\begin{array}{c}\text { Durbin-Watson } \\
\text { statistic }\end{array}$ \\
\hline \multirow{3}{*}{ B. serrulatum } & $1^{*}$ & 161.0 & 11.188 & 88.768 & 0.626 \\
& 2 & 327.648 & 13.588 & 63.609 & 0.259 \\
& 3 & 380.448 & 14.343 & 51.376 & 0.251 \\
P. feuillei & 1 & 296.233 & 14.251 & 57.900 & 0.088 \\
& 2 & 160.068 & 9.820 & 84.144 & 0.091 \\
& 3* & 80.825 & 7.211 & 93.616 & 0.181
\end{tabular}

$\left.{ }^{*}\right)$ best model selected for further analysis.

Table 6. Model comparison in B. serrulatum

\begin{tabular}{lccc}
\hline & Logistic model & Gompertz model & F-test \\
\hline RSS & 2737.0 & 1373.860 & 0.0158 \\
RMSE & 12.688 & 9.266 & \\
\hline
\end{tabular}

$\mathrm{n}=18, F(1,16)=4.49, \alpha=0.05$

Table 7. Model comparison in P. feuillei

\begin{tabular}{lccc}
\hline & Logistic model & Gompertz model & F-test \\
\hline RSS & 1697.340 & 56.637 & 579.548 \\
RMSE & 8.990 & 1.682 & \\
\hline
\end{tabular}

$\mathrm{n}=22, F(1,20)=4.35, \alpha=0.05$.
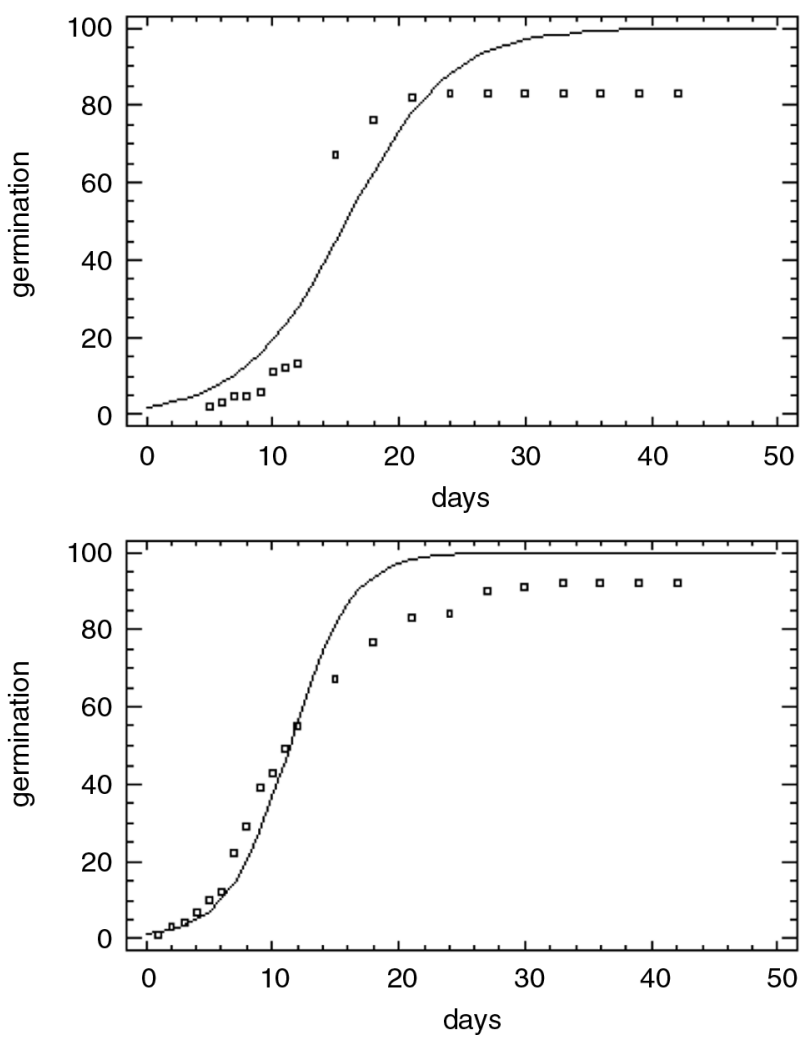

Fig. 8. Spores germination curve over days illustrating the nature of the logistic function for B. serrulatum (top) and P. feuillei (bottom). 
square error (RMSE), the Gompertz regression model was better fit than logistic regression. However, according to $F$-test in P. feuillei the Gompertz germination model remained the best-fit model.

\section{DISCUSSION}

Several S-shaped curves have been proposed to describe germination in a variety of plants, bryophytes, fungi, etc: polynomial regression and logistic (Hsu \& al., 1984; Dantigny \& al., 2011), normal cumulative curve (Waggoner \& Parlange, 1973), Gompertz (Wiklund \& Rydin, 2004), Weibull (Brown \& Mayer, 1988), inverse normal distribution (O'Neill \& al., 2004) and some other are usually the chosen functions when modelling the germination of seeds and spores. However, most studies assume that cumulative germination follows a Gompertz or logistic model. Other models like those where data are fitted to polynomials exhibit some problems in the biological interpretation of parameters (Fitzhugh, 2011). It is important to note that both Gompertz and logistic germination functions exhibit an inflection point, but whereas logistic function is symmetrical with respect to that point, the Gompertz curve is not. In any case, both functions are special cases of Richards function. Furthermore, the logistic function is very similar to the cumulative normal distribution and so perfectly symmetrical. However, germination is always skewed because of late-germination seeds or spores. According to our experiments and in agreement with previous authors (Brown \& Mayer, 1988) the Gompertz function should be used as it better describes the phenomenon of germination. In the model, the estimates of $\alpha$ and $r$ parameters were obtained using a classical approach (see Appendix). However, the parameters of the Gompertz curve could be estimated using different methods, e.g. using the grey direct modelling (Wu \& Wang, 2009), artificial neural networks (Roush \& al., 2006), etc. We found that Gompertz and logistic functions were insensitive to the initial estimates of parameters and converged from initial values markedly different. This fact was observed previously (Brown \& Mayer, 1988) as a major feature of Gompertz and logistic models. Other germination models are sensitive to the choice of initial estimates of parameters, being difficult the analysis of the nonlinear regression germination model, which is also related with the iterative nature of the computational algorithm (Marquardt, 1963) used to find a least square solution. Note that regression analysis cannot be done using matrix algebra, as it is usual in linear regression.

\section{Influence of ecophysiological factors on the curve dynamics}

A first observation worthy of notice among the studied species was a case of non-convergence when studying spore germination for the species Cheilanthes glauca. A two steps germination model has been occasionally reported in literature arising as a consequence of a mixture of spore populations. In such a case late-germinating seeds split the plateau of the cumulative germination function in two asymptotes or steps: the first step for the early germinating seeds and the second for late-germinating seeds.

Quiescence is the phenomenon by which fern spores can rapidly germinate when faced up to optimal conditions (humidity, atmosphere, nutrients and temperature).
Dormancy is defined as the set of characters that derived in the failure of quiescent spores to germinate (Raghavan, 1989). This set of characters is assumed to be regulated by some kind of physical and chemical changes in the spore, established during its maturation. Only when some conditions are met, the chemical state is reversed and the spore is able to germinate. Many aspects are known to be affecting dormancy, as light, temperature, water and hormonal conditions (Weinberg \& Voeller, 1969). In the Gompertz model we are proposing $r$ could be interpreted as the set of endogenous changes forced by environmental conditions (both extrinsic and intrinsic) that move spores from a dormant state to a quiescent state. Once achieved the set of changes at a time by a pool of individuals in the spore population they manifest germination. As the environmental conditions are promoting the endogenous changes with time, under suitable conditions, more and more spores tend to germinate. The presence of chlorophyll in the cell (green spores) is clearly affecting the germination model, because these spores show no o limited dormancy (Lloyd \& Klekowski, 1970). The effect of chlorophyll in the spores has not been considered in this work, as all the species presented nongreen spores.

It is remarkable that in some of our cultures the maximum germination rate is achieved at a lower percentage than in others, regardless of the environmental conditions. There are some presumable factors that could explain in part this phenomenon but none of them offers a complete explanation (Gabriel y Galán \& Prada, 2010c). Nevertheless, those factors could conform a set of characters represented by $\alpha$ in our model. We propose three of these factors with different biological meanings. The first factor is resources depletion, which represents the influence of the physical environment on germination. At the beginning of the germination the Petri dishes contain enough nutritive agar medium. Only when gametophytes reach a certain size environmental resources become limiting. The second one is population density, which is representing the intraspecific ecological relationships. It is certainly true that culture density is affecting the development of gametophytes (including size and shape at maturity and gametangia production), with a positive relation to the yet cited resource availability; but to date evidence that density affects germination per se is still controversial (Ashcroft \& Sheffield, 2000). A third factor is the age of the spore, defined as the time elapsed from meiosis, which represents an endogenous force with individual variation. Although in our experiments the influence of age has been controlled (as all the spores were cultured with less than a month), it is well known that in ferns, the older the spores are the less rate of germination is achieved (Conway, 1949; Smith \& Robinson, 1975; Gabriel y Galán \& Prada, 2010c). Thus, age of spores is a factor implicitly represented by $\alpha$ in our germination model. Furthermore, if environmental resources and population density do not affect germination, $\alpha$ represents primarily the effect of age. It could be of interest for a future to culture spores of the same species but of different ages to see how the Gompertz regression model is affected by this parameter. In growth curves in animals the biological interpretation of parameters depends on the relationships between genetics and environment (Fitzhugh, 2011). However, we guess that in plants the biological meaning of parameters could be related for the most part with environment, e.g. resources, 
population density, etc. showing a lower influence the physiological factors, e.g. the seed/spore age.

\section{CONCLUSIONS}

Gompertz function proved a valuable tool for fitting germination in Blechnum serrulatum, Blechnum yungense, Cheilanthes pilosa, Niphidium macbridei and Polypodium feuillei species. We can conclude that the Gompertz model could represent the model of germination for all the nongreen spore leptosporangiate ferns. The two parameters of the regression model have biological meaning. In particular, $r$ collects those events that promote germination, for instance light, humidity, hormones, etc. whereas $\alpha$ represents events that retard or inhibit germination such as resource depletion, population density and, in artificial cultures, mainly the spore age.

\section{REFERENCES}

Angell, A. C. \& Kielland, K. 2009. Establishment and growth of white spruce on a boreal forest floodplain: Interactions between microclimate and mammalian herbivory. Forest Ecology and Management 258, 2475-2480. http://dx.doi.org/10.1016/j.foreco.2009.08.030

Ashcroft, C. J. \& Sheffield, E. 2000. The effect of spore density on germination and development in Pteridium, monitored using a novel culture technique. American Fern Journal 90: 91-99. http://dx.doi.org/ $10.2307 / 1547324$

Baskin, C. C. \& Baskin, J. M. 1998. Seeds: ecology, biogeography, and evolution of dormancy and germination. San Diego, CA. Academic Press.

Bewley, J. D. 1997. Seed germination and dormancy. Plant Cell 9: 1055-1066. http://dx.doi.org/10.1105/tpc.9.7.1055

Bosch, A., Maronna, R. A. \& Yantorno, O. M. 1995. A simple descriptive model of filamentous fungi spore germination. Process Biochemistry 30 : 599-606. http://dx.doi.org/10.1016/0032-9592(94)00007-7

Bradbeer, J. W. 1988. Seed dormancy and germination. Glasgow. Blackie and Son Ltd

Brown, R. F. \& Mayer, D. G. 1988. Representing Cumulative Germination. 2. The Use of the Weibull Function and Other Empirically Derived Curves. Annals of Botany 61: 127-138

Cheng, C. \& Gordon, I. L. 2000. The Richards function and quantitative analysis of germination and dormancy in meadowfoam (Limnanthes alba). Seed Science Research 10: 265-277.

Conway, E. 1949. The autecology of bracken (Pteridium aquilinum (L.) Kuhn) The germination of the spore, and the development of the prothallus and the young sporophyte. Proceeding of the Royal Society of Edinburgh 63 B: 325-342. http://dx.doi.org/10.1017/s0080455x00011966

Dantigny, P., Nanguy, S-M., Judet-Correia, D. \& Bensoussan, M. 2011. A new model for germination of fungi. International Journal of Food Microbiology 146: 176-181.

Draper, N. \& Smith, H. 1998. Applied regression analysis. New York. John Wiley \& Sons. http://dx.doi.org/10.1002/9781118625590

Dyer, A. 1979. The culture of fern gametophytes for experimental investigation. In: A. Dyer (ed.) The experimental biology of ferns: 254-305. London.

Finch-Savage, W. E. \& Leubner-Metzger, G. 2006. Seed dormancy and the control of germination. New Phytologist 171: 501-523. http://dx.doi. org/10.1111/j.1469-8137.2006.01787.x

Fitzhugh, H. A. 2011. Analysis of growth curves and strategies for altering their shape. Journal of Animal Science 42: 1036-1051.

Gabriel y Galán, J. M. 2010. Gametophyte development and reproduction of Niphidium macbridei Lellinger (Polypodiaceae, Pteridophyta). Nova Hedwigia 90: 513-519.

Gabriel y Galán, J. M. 2011. Gametophyte development and reproduction of Argyrochosma nivea (Poir.) Windham (Pteridaceae). Biologia 65: 50-54.

Gabriel y Galán, J. M., Migliaro, G. \& Lahoz-Beltrá, R. 2011. Effect of temperature and dark pre-treatment in the germination of three species of Jamesonia (Pteridaceae, Polypodiopsida). Plant Species Biology 26: 254-258. http://dx.doi.org/10.1111/j.1442-1984.2011.00327.x

Gabriel y Galán, J. M., Passarelli, L. M., Prada, C. \& Rolleri, C. H. 2008a. Sporophyte morphology and gametophyte development of the fern
Blechnum sprucei (Pteridophyta: Blechnaceae). Revista De Biologia Tropical 56: 2027-2040.

Gabriel y Galán, J. M. \& Prada, C. 2009. Gametophytes of Pleurosorus papaverifolius (Kunze) Fee (Aspleniaceae) and Cheilanthes glauca (Cav.) Mett. (Pteridaceae), two South American fern. Acta Botanica Brasilica 23: 805-811. http://dx.doi.org/10.1590/S0102-33062009000300021

Gabriel y Galán, J. M. \& Prada, C. 2010a. Gametophyte of the Andean fern Cheilanthes pilosa Goldm. (Pteridaceae). American Fern Journal 100: 32-38. http://dx.doi.org/10.1640/0002-8444-100.1.32

Gabriel y Galán, J. M. \& Prada, C. 2010b. Gametophyte of the Andean fern Polystichum pycnolepis (Kunze ex Klotzsch) T. Moore (Dryopteridaceae). American Fern Journal 100: 103-109. http://dx.doi. org/10.1640/0002-8444-100.2.103

Gabriel y Galán, J. M. \& Prada, C. 2010c. Pteridophyte spores viability. In: H. Fernández, A. Kumar \& M. A. Revilla (eds.), Working with ferns: issues and applications: 193-205. New York.

Gabriel y Galán, J. M. \& Prada, C. 2012. Farina production by gametophytes of Argyrochosma nivea (Poir.) Windham (Pteridaceae) and its implications for cheilanthoid phylogeny. American Fern Journal 102: 191-197. http://dx.doi.org/10.1640/0002-8444-102.3.191

Gabriel y Galán, J. M., Prada, C. \& Rolleri, C. H. 2008b. Germinación de la espora y desarrollo del gametófito del helecho americano Polypodium feuillei Bert. Gayana Botanica 65: 14-22.

Goodchild, N. A. \& Walker, M. G. 1971. A method of measuring seed germination in physyiological studies. Annals of Botany 35: 615-621.

Hsu, F. H., Nelson, C. J. \& Chow, W. S. 1984. A mathematical-model to utilize the logistic function in germination and seedling growth. Journal of Experimental Botany 35: 1629-1640. http://dx.doi.org/10.1093/jxb/ 35.11.1629

Lapp, M. S. \& Skoropad, W. P. 1976. A mathematical model of conidial germination and appressorial formation for Colletotrichum graminicola. Canadian Journal of Botany 54: 2239-2242. http://dx.doi.org/10.1139/b76-240

Lloyd, R. \& Klekowski, E. J. 1970. Spore germination and viability in pteridophyta: evolutionary significance of chlorophyllous spores. Biotropica 2: 129-137. http://dx.doi.org/10.2307/2989770

Maguire, J. D. 1962. Speed germination-aid in selection and evaluation for seedling emergence and vigour. Crop Science 2: 176-177. http://dx.doi. org/10.2135/cropsci1962.0011183X000200020033x

Marquardt, D. 1963. An algorithm for least-squares estimation of nonlinear parameters. Journal of the Society for Industrial and Applied Mathematics 11: 431-441. http://dx.doi.org/10.1137/0111030

Migliaro, G. \& Gabriel Y Galán, J. M. 2012. Gametophyte development and reproduction of the Asian fern Polystichum polyblepharum (Roem. ex Kunze) C. Presl (Dryopteridaceae, Polypodiopsida). Plant Biosystem 146: 368-373. http://dx.doi.org/10.1080/11263504.2011.651505

Neter, J., Kutner, M. H., Nachtsheim, C. J. \& Wasserman, W. 1996. Applied Linear Statistical Models. Richard D. Irwin, Inc., Chicago, IL.

O'Neill, M., Thompson, P., Jacobs, B., Brain, P., Butler, R., Turner, H. \& Mitakda, B. 2004. Fitting and comparing seed germination models with a focus on the inverse normal distribution. Australian \& New Zealand Journal of Statistics 46: 349-366.

Myers, R. H. 1990. Classical and Modern Regression with Applications. Duxbury Press, Belmont, CA.

Prada, C. 2004. Helechos. In: J. Izco (ed.) Botánica: 385-415. Madrid.

Prada, C., Moreno, V. \& Gabriel Y Galan, J. M. 2008. Gametophyte development, sex expression and antheridiogen system in Pteris incompleta Cav. (Pteridaceae). American Fern Journal 98: 14-25. http://dx.doi. org/10.1640/0002-8444(2008)98[14:GDSEAA]2.0.CO;2

Raghavan, V. 1989. Developmental biology of fern gametophytes. Cambridge. University Press. http://dx.doi.org/10.1017/CBO9780511529757

Ranal, M. A. \& Garcia De Santana, D. 2006. How and why to measure the germination process? Revista Brasileira de Botânica 29: 1-11. http:// dx.doi.org/10.1590/S0100-84042006000100002

Roush, W. B., Dozier, W. A. \& Branton, S. L. 2006. Comparison of Gompertz and neural network models of broiler growth. Poultry Science 85: 794-797. http://dx.doi.org/10.1093/ps/85.4.794

Sheffield, E. 1996. From pteridophyte spore to sporophyte in the natural environment. In: M. G. J. M. Camus, R. Johns (ed.) Pteridology in Perspective: $541-549$. Kew.

Smith, D. L. \& Robinson, P. M. 1975. Effects of spore age on germination and gametophyte development in Polypodium vulgare L. New Phytologist 74 101-108. http://dx.doi.org/10.1111/j.1469-8137.1975.tb01344.x

Stat Trek. 2012. Statistics: Influential points. http://stattrek.com/

Thompson, P. A. 1973. Seed germination in relation to ecological and geographical distribution. In: V. A. Heywood (ed.) Taxonomy and ecology: 93-119. London. 
Torres, M. \& Frutos, G. 1990. Analysis of germination curves of aged fennel seeds by mathematical-models. Environmental and Experimental Botany 29: 409-415. http://dx.doi.org/10.1016/0098-8472(89) 90016-6

Waggoner, P. E. \& Parlange, J.-Y. 1973. Mathematical model for spore germination at changing temperatures. Phytopathology 64: 605-610. http:// dx.doi.org/10.1094/Phyto-64-605

Weinberg, E. S. \& Voeller, B. R. 1969. Induction of fern spore germination. Proceedings of the National Academy of Sciences of the

\section{Appendix}

Germination at a given day $t$ was fitted for each experimental replicate (Petri dish) by non-linear regression to a Gompertz growth model (Draper \& Smith, 1998):

$$
y=y_{0} \exp \left[\frac{r}{\alpha}\left(\exp \left(-\alpha t_{0}\right)-\exp (-\alpha t)\right)\right]
$$

where $y$ is the germination rate, $t$ is the time (days), $y_{0}$ is the germination rate at initial time $t_{0}$ and two parameters: the instantaneous germination rate $r$, and, $\alpha$ the rate of decrease of $r$.

The nonlinear equations were fitted to germination data by nonlinear regression. The Gompertz nonlinear regression was conducted with the Marquardt's algorithm (Marquardt, 1963) as implemented in the statistical package STATGRAPHICS 5.1 (Statistical Graphics Corporation). This iterative method uses the initial estimates of parameters $\left(\alpha_{i} r_{i}\right)$ and the Gomperzt function supplied in the form shown in (1). The method minimizes the sum of the squares of the differences between the predicted and experimental data.

Initial estimates of the parameters $\alpha$ and $r$ were empirically obtained. Using the following equation:

$$
y=y_{0} \exp \left[\frac{r}{\alpha}\left[\exp \left(-\alpha t_{0}\right)\left[1-\exp \left(-\alpha\left(t-t_{0}\right)\right)\right]\right]\right]
$$

we can obtain the expression:

$$
1-\exp \left(-\left(t-t_{0}\right) \alpha\right)=\frac{\operatorname{Ln}\left(\frac{y}{y_{0}}\right)}{\operatorname{Ln}\left(\frac{K}{y_{0}}\right)}
$$

which was solved using the program DERIVE 6 (Texas Instruments Incorporated). According to the asymptotic $y$ value at $t \rightarrow+\infty$ the Gompertz function becomes:

$$
\lim _{t \rightarrow \infty} y=y_{0} \exp \left(\frac{r}{\alpha} \exp \left(-\alpha t_{0}\right)\right)=K
$$

where $K$ is the maximum germination rate, thus 100. From (4) we obtain:

$$
\frac{r}{\alpha}=\exp \left(\alpha t_{0}\right) \cdot \operatorname{Ln}\left(\frac{K}{y_{0}}\right)
$$

Likewise (3), expression (5) was solved with DERIVE program.

Once we obtain $\alpha$ in expression (3), its value is used in (5). Solving expression (5) we obtain the $r$ value. After that $(\alpha, r)$ will be the initial estimate of the model parameters. Nonlinear regression requires we supply the initial values of model parameters (Draper and Smith, 1988; Neter et al., 1996; Myers, 1990). Since the convergence of the model could depend on the initial estimates of parameters, we proceeded performing the statistical analysis several times using different initial estimates, as follows. First, we calculated $\alpha$ at different germination times $t_{1}, t_{2}, \ldots t_{n}$, and then we obtained the parameter values. $\left(\alpha_{1}, r_{1}\right),\left(\alpha_{2}, r_{2}\right), \ldots\left(\alpha_{n}, r_{n}\right)$ Germination times were selected according to our understanding of the relevance of a data point in the germination experiment. Secondly, the fit of the predictive model was conducted using the statistical package STATGRAPHICS. The initial estimates of parameters $\left(\alpha_{1}, r_{1}\right),\left(\alpha_{2}, r_{2}\right), \ldots\left(\alpha_{n}, r_{n}\right)$ were used for each one of a preliminary nonlinear regression analysis model. The method then calculates the parameters with lowest residual sum, thus
United States of America 64: 835-842. http://dx.doi.org/10.1073/pnas. 64.3 .835

Wiklund, K. \& Rydin, H. 2004. Ecophysiological constraints on spore establishment in bryophytes. Functional Ecology 18: 907-913. http:// dx.doi.org/10.1111/j.0269-8463.2004.00906.x

Wu, L. \& Wang, Y. (2009). Fitting Gompertz curve using grey method. In: Proceedings of the 2009 IEEE International Conference on Systems, Man and Cybernetics. pp. 5093-5096. San Antonio. http://dx.doi.org/10.1109/ ICSMC.2009.5346025

$\left(\alpha_{1}^{*}, r_{1}^{*}\right),\left(\alpha_{2}^{*}, r_{2}^{*}\right), \ldots\left(\alpha_{n}^{*}, r_{n}^{*}\right)$ reporting the best-fit results. Third, we tested the fit of the predictive models selecting the model $\left(\alpha_{i}^{*}, r_{i}^{*}\right)$ with the lowest error measurements indices and highest coefficient of determination $R^{2}$. The mean square error (MSE) was computed as:

$$
\text { MSE }=\frac{\sum_{t=1}^{n}\left(y_{t}-y_{t}^{*}\right)^{2}}{n}
$$

where $y_{t}$ and $y_{t}^{*}$ are the observed and the predicted germination values respectively. The mean absolute error (MAE) was computed as:

$$
\text { MAE }=\frac{\sum_{t=1}^{n}\left[y_{t}-y_{t}^{*}\right]}{n}
$$

Finally, in the selected model (thus $\left(\alpha_{i}^{*}, r_{i}^{*}\right)$, the model marked with asterisk * in Table 2) we conducted an analysis to detect influential points (Angell and Kielland, 2009; Stat Trek, 2012), which were removed in further analysis. Statistical tools in STATGRAPHICS were used to detect observations that have leverage values, unusually large DIFTS (influence of an observation in the estimated parameter, thus $\alpha$ and $r$ ) or Cook's distance values (distance between the estimated parameters with and without such observation). Once such observations were removed the final nonlinear equations were fitted to germination data by nonlinear regression.

A comparison was made between the modelling by the Gompertz nonlinear regression equation and the logistic equation:

$$
y=\frac{y_{0} k}{y_{0}+\left(k-y_{0}\right) \exp (-r t)}
$$

where $y$ is the germination rate, $t$ is the time (days), $y_{0}$ is the germination rate at initial time $t_{0}, k$ is the carrying capacity (the maximum sustainable germination) and $r$ is the instantaneous germination rate. We compared the best fitted experimental replicate to logistic equation with its fitting to the Gompertz equation. Following, we conducted an F-test to compare both models. The $F$ ratio is calculated by comparing the relative difference in the residual sum of squares (RSS) between logistic and Gompertz models with the residual sum of squares of Gompertz model. When comparing Gompertz model with logistic model, the F-ratio is given by:

$$
F=\frac{\left(\frac{R S S_{L}-R S S_{G}}{p_{G}-p_{L}}\right)}{\left(\frac{R S S_{G}}{n-p_{G}}\right)}
$$

where $p_{G}, p_{L}$ and $n$ are the number of parameters in the Gompertz model $\left(p_{G}=2\right)$, the parameters in the logistic model $\left(p_{L}=1\right)$ and the number of data points to estimate parameters, respectively. Under the null hypothesis that Gompertz model does not provide a significantly better fit than logistic model, $F$ will have an $F$ distribution with $p_{G}-p_{L}, n-p_{G}$ degrees of freedom. 